\title{
First and short syntheses of biologically active, naturally occurring brominated mono- and dibenzyl phenols
}

\author{
Halis T. Balaydın, Yusuf Akbaba, Abdullah Menzek,* Ertan Şahin, \\ and Süleyman Göksu* \\ Department of Chemistry, Faculty of Science, Ataturk University, 25240 Erzurum, Turkey \\ E-mail:amenzek@atauni.edu.tr,sgoksu@atauni.edu.tr
}

\begin{abstract}
First and short syntheses of biologically active, naturally occurring 3,4,6-tribromo-5-(2,3dibromo-4,5-dihydroxybenzyl)benzene-1,2-diol 3, 3,4,6-tribromo-5-(2,3,6-tribromo-4,5dihydroxybenzyl)benzene-1,2-diol 4 and 3,4-dibromo-5-[3-bromo-2-(2,3-dibromo-4,5dihydroxybenzyl)-4,5-dihydroxybenzyl]benzene-1,2-diol 5 from the red alga were carried out.
\end{abstract}

Keywords: Bromination, bromophenols, red algae, natural product, synthesis

\section{Introduction}

Naturally occurring bromophenols are found in marine life and frequently isolated from red algae of the family Rhodomelaceae. ${ }^{1}$ Most of these compounds have important biological activities. $^{1-4}$ For example, bromophenols 1 and 2 (Figure 1) exhibit enzyme inhibition, ${ }^{2 a}$ cytotoxicity, $^{2 \mathrm{~b}}$ feeding deterrent, ${ }^{2 \mathrm{c}}$ and microbial $^{2 \mathrm{~d}, \mathrm{e}}$ activities. Protein tyrosine phosphatase inhibitory activity of bromophenol 1 was also reported. ${ }^{2 f, g}$

Monobenzylphenol derivatives 3,4,6-tribromo-5-(2,3-dibromo-4,5dihydroxybenzyl)benzene-1,2-diol 3 and 3,4,6-tribromo-5-(2,3,6-tribromo-4,5dihydroxybenzyl)benzene-1,2-diol 4, first isolated from the red alga Symphyocladia latiuscula in 2005 by Wang et al. (Figure 1), were reported to exhibit significant aldose reductase inhibitory activity. ${ }^{3 a}$ On the other hand, antioxidant activity of bromophenol 4 was also noted. ${ }^{3 \mathrm{~b}}$ In 2003 , Fan et al. reported the first isolation of dibenzylphenol derivative 3,4-dibromo-5-[3-bromo-2(2,3-dibromo-4,5-dihydroxybenzyl)-4,5-dihydroxybenzyl]benzene-1,2-diol $\mathbf{5}$ from red alga Rhodomela confervoides (Figure 1). ${ }^{4}$ The extracts of bromophenols including 5 from red alga were used for the treatment of rats with diabetes as an inhibitor of protein tyrosine phosphatase. $^{2 \mathrm{f}, \mathrm{g}}$ 

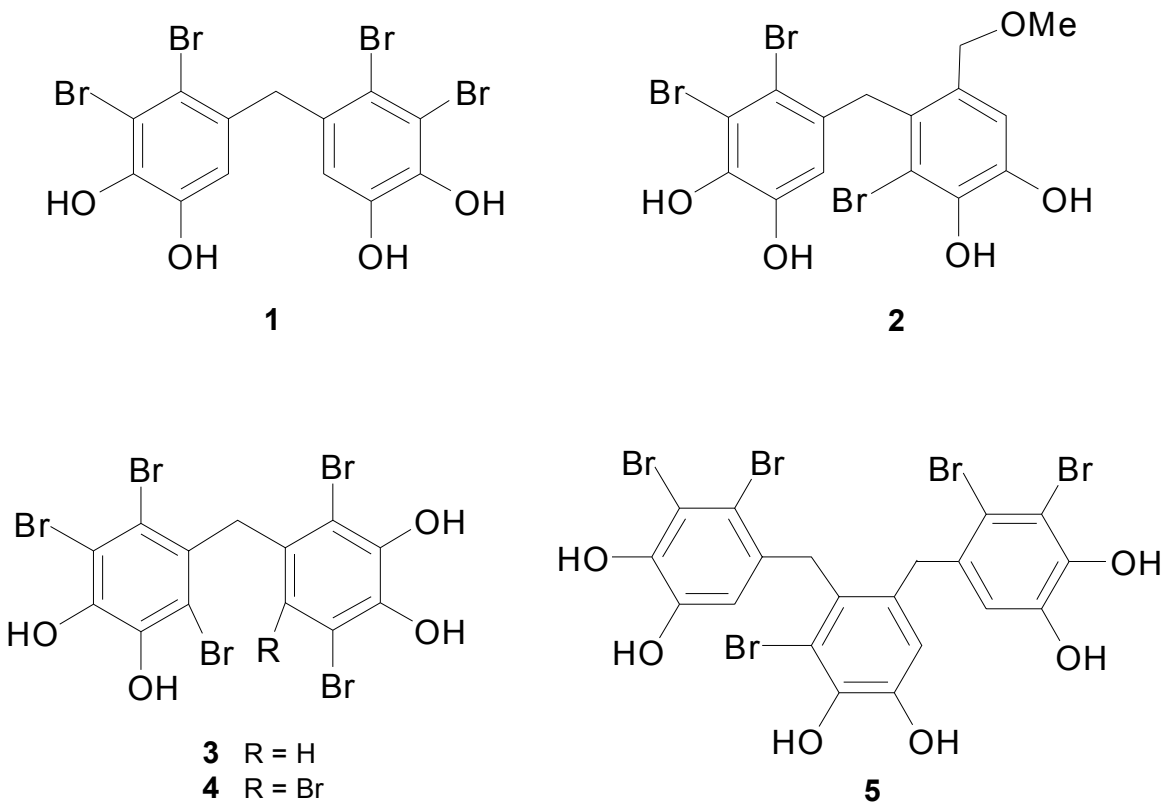

Figure 1. Biologically active natural products, bromophenols.

To our knowledge, biologically active natural products, bromophenols $\mathbf{3}, \mathbf{4}$ and $\mathbf{5}$, have not yet been synthesized. In the present study, we report on the first synthesis of these natural products $\mathbf{3}, \mathbf{4}$ and $\mathbf{5}$.

\section{Results and Discussion}

Bromophenols 3, $\mathbf{4}$ and $\mathbf{5}$ as biologically active natural products are highly brominated monoand dibenzyl phenols (Figure 1). One ring of $\mathbf{3}$ and two rings of $\mathbf{5}$ are dibrominated pyrocatechol derivatives while both rings of $\mathbf{4}$, a symmetric molecule, are tri-brominated pyrocatechol derivatives. One ring of $\mathbf{3}$ and $\mathbf{4}$ is a tri-brominated pyrocatechol derivative and these rings are the same. For the synthesis of these compounds, our method is based on the preparation of aromatic rings with $\mathrm{Br}$, followed by their connection. For these purposes, acetylation of $(3,4-$ dimethoxyphenyl)methanol 6 with $\mathrm{Ac}_{2} \mathrm{O}^{5,6}$ (acetic anhydride)/pyridine was performed to give 3,4-dimethoxybenzyl acetate 7 in in high yield. From this acetate 7, bromoalcohol 9 was synthesized via 8 (Scheme 1). ${ }^{6}$ On the other hand, tribromoveratrole $13^{7}$ was also obtained via 10-12 (Scheme 1) for the preparation of the other ring of 4. Methyl protection of starting materials is necessary to prevent side reactions and purification-characterization difficulties. Therefore, phenolic reagents were methylated or purchased as methylated. 


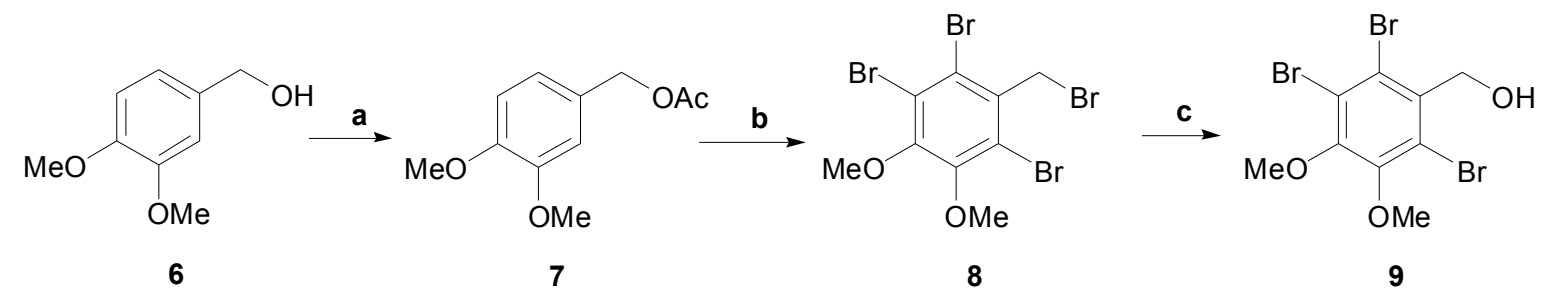

6

7

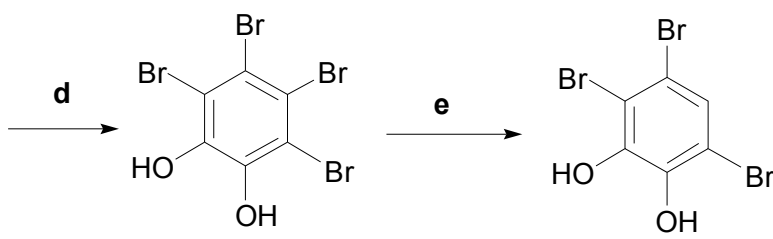

11

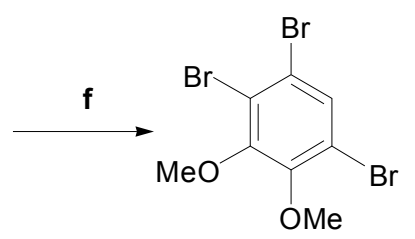

13

Scheme 1. Synthesis of 9 and 13. a) $\mathrm{Ac}_{2} \mathrm{O} /$ pyridine, $25{ }^{\circ} \mathrm{C}, 97 \%$; b) $\mathrm{Br}_{2} / \mathrm{Fe}, \mathrm{AcOH}, 18 \%$; c) dioxane/water, reflux, 90\%; d) $\mathrm{Br}_{2}$ (8 eq.)/AcOH, $120{ }^{\circ} \mathrm{C}$, quantitative; e) $\mathrm{Zn} / \mathrm{AcOH}, 120{ }^{\circ} \mathrm{C}$, $20 \%$; f) $\left(\mathrm{CH}_{3}\right)_{2} \mathrm{SO}_{4} / \mathrm{K}_{2} \mathrm{CO}_{3}$, THF, reflux, $98 \%$.<smiles>COc1c(Br)c(Br)c(CO)c(Br)c1OC</smiles>

9<smiles>COc1c(C)c(Br)c(Br)c(OC)c1C</smiles>

9

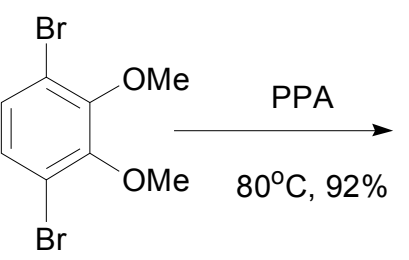

14

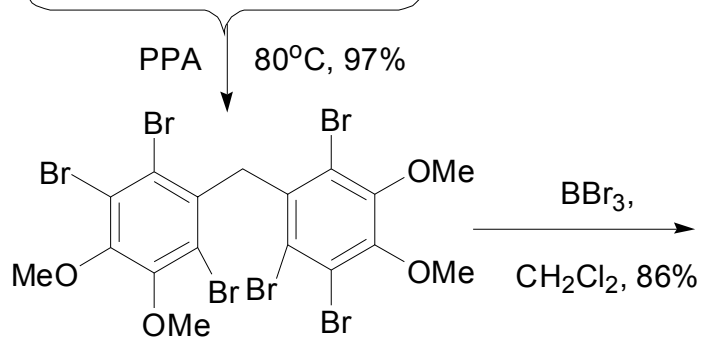

16

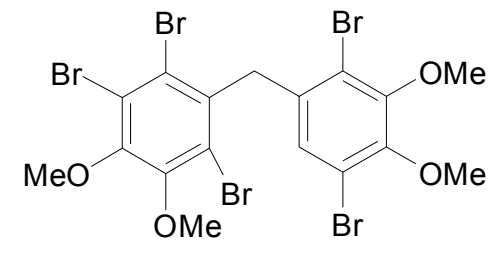

15

$\mathrm{BBr}_{3}, \quad \mathrm{CH}_{2} \mathrm{Cl}_{2}, 88 \%$<smiles>OCC(Br)CCCC(Br)CBr</smiles>

$\mathrm{HO} \int_{\mathrm{OH}} \mathrm{Br}$

3

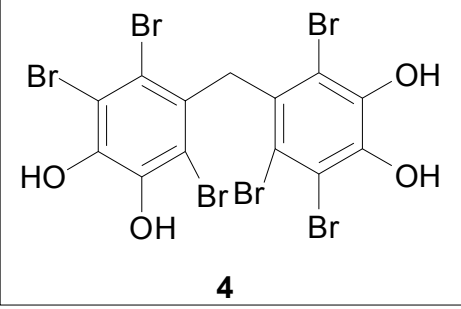

Scheme 2. Synthesis of biologically active natural products 3 and 4 . 
Bromoalcohol 9 was reacted with both 13 to give 16, and $14^{8}$ to give 15 in the $\mathrm{PPA}^{9}$ (polyphosphoric acid) at $80^{\circ} \mathrm{C}$ (Scheme 2). Monobenzyl phenol derivatives $\mathbf{1 5}$ and $\mathbf{1 6}$ were obtained in high yields in their reactions as a sole product. According to their NMR data, 15 is unsymmetrical while 16 is symmetric. Protons of $\mathbf{1 5}$ resonate at 6.48, 4.49, 3.96, 3.93 and 3.89 ppm as singlet (s) with relative intensities of 1:2:3:6:3, while protons of 16 resonate at $4.91,3.90$ and $3.87 \mathrm{ppm}$ with relative intensities of 1:3:3 as s. NMR data of $\mathbf{1 5}$ and $\mathbf{1 6}$ are consistent with the proposed structures. They are precursor compounds of natural products 3 and 4 , respectively.

Monobenzyl phenols 3, 4 were first synthesized from 15 and 16 by ether cleavage with $\mathrm{BBr}_{3}{ }^{10}$ (Scheme 2). Data such as NMR of $\mathbf{3}$ and $\mathbf{4}$ were consistent with the literature. ${ }^{3 \mathrm{a}}$ Total yields of 3 and $\mathbf{4}$ are $13 \%$ starting from commercial product 6.

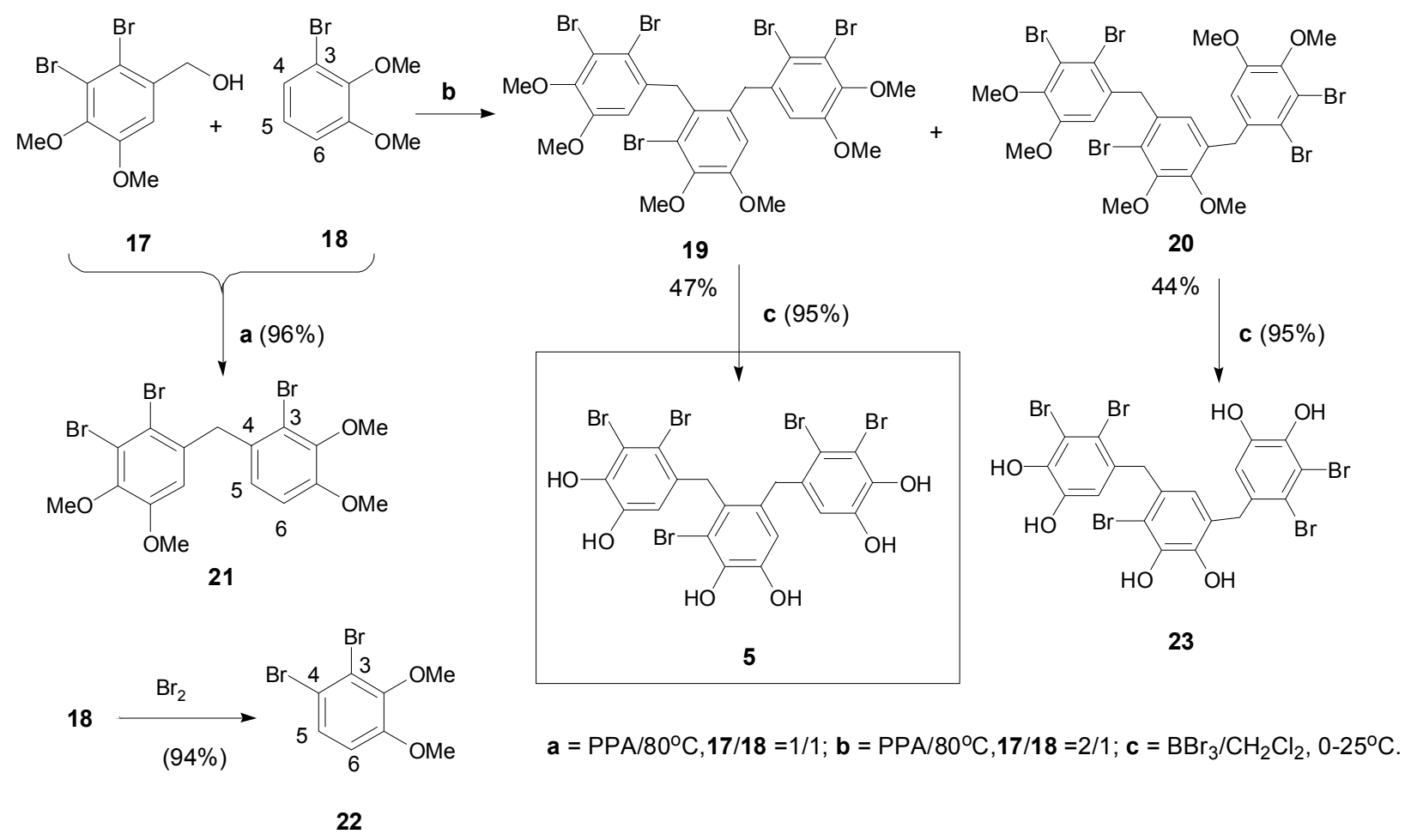

Scheme 3. Synthesis of biologically active natural product $\mathbf{5}$ and its derivative 23.

In the structure of bromophenol 5, brominated dibenzyl phenol derivative, there are two 2,3dibromo-4,5-dihydroxybenzyl and one 3-bromo-catechol units. Firstly, (2,3-dibromo-4,5dimethoxyphenyl)methanol $\mathbf{1 7}^{11}$ and 1-bromo-2,3-dimethoxybenzene $\mathbf{1 8}^{12}$ were synthesized for these units by following the procedures described in the literature. Secondly, reaction of 17 (2 equivalent) with 18 ( 1 equivalent) gave two isomeric pentabromides. Protons of one of them resonate at $6.61,6.58,6.36,4.12,4.01,3.90,3.85,3.84,3.82,3.73$ and $3.72 \mathrm{ppm}$ as $\mathrm{s}$ with relative intensities of $1: 1: 1: 2: 2: 3: 3: 3: 3: 3: 3$, while protons of the other resonate at $6.60,6.45$, $6.14,4.20,3.96,3.88,3.80,3.79,3.78,3.71$ and $3.57 \mathrm{ppm}$ as $\mathrm{s}$ with relative intensities of 
$1: 1: 1: 2: 2: 3: 3: 3: 3: 3: 3$. Tri-isomeric pentabromides may be formed as a result of this reaction because they are disubstituted products of $\mathbf{1 8}$.

Their formations should be a sequential disubstitution to 18. Monosubstituted product(s) may provide information about these disubstituted isomeric products. To this end, reaction of 17 with 18 in equimolar (1:1) was performed, and a monosubstituted product was obtained from this reaction as the sole product. The presence of an $\mathrm{AB}$ system in the ${ }^{1} \mathrm{H}-\mathrm{NMR}$ spectrum of this product shows that substitution may occur at C-4 or C-6 in 18. To be sure of the place of the monosubstitution in $\mathbf{1 8}$, bromination of $\mathbf{1 8}$ was performed and dibromoveratrole was obtained as the sole product. Dibromoveratrole should be $\mathbf{2 2}$ because other dibromides such as $\mathbf{1 4}$ do not give an AB-system in the aromatic region of their ${ }^{1} \mathrm{H}-\mathrm{NMR}$ spectra. Therefore, the monosubstitution product should be 21 .

Substitution at C-5 or C-6 atoms in $\mathbf{2 1}$ may give two isomeric products. They will be disubstituted isomeric products obtained from the reaction of $\mathbf{1 7}$ with $\mathbf{1 8}$. According to the NMR spectra of disubstituted isomeric products, it is not easy to establish their exact configurations. Therefore, the exact structure of one of them was determined by X-ray crystallographic analysis (Figure 2). ${ }^{13}$ This isomer is pentabromide 19 which is a precursor compound for the natural compound 5. The other disubstituted product should be 20. NMR data of 19-22 are also consistent with the proposed structures.

The molecular structure of the pentabromide 19 was successfully determined using singlecrystal X-ray diffraction analysis. The unit cell of pentabromide 19 comprises two centrosymmetric molecules $\left(\mathrm{C}_{26} \mathrm{H}_{24} \mathrm{Br}_{5} \mathrm{O}_{6}\right)$ which, however, in spite of the considerable structural similarity, are structurally inequivalent to each other (see Figure 2). Therefore, X-ray structure determination of pentabromide 19 revealed that the asymmetric unit contains two independent conformational isomers, which are (conformers in 3-D) due to rotations about $\sigma$-bonds (the different rotation of methoxy about the $\mathrm{C}_{\text {phenyl }}-\mathrm{O} 2$ and $\mathrm{C}_{\text {phenyl }}-\mathrm{O} 2$ ' bonds). Moreover, in both conformers edge phenyl rings are considerably folded on each other. (distance between $\mathrm{C} 5 / \mathrm{C} 10$ and $\mathrm{C} 15 / \mathrm{C} 20$ phenyl ring centroid is 3.777(6) $\AA$; $\mathrm{C}^{\prime} / \mathrm{C} 10^{\prime}$ and $\mathrm{C} 15^{\prime} / \mathrm{C} 20^{\prime}$ ring centroid is 3.781(6) Å) (Figure 3). 


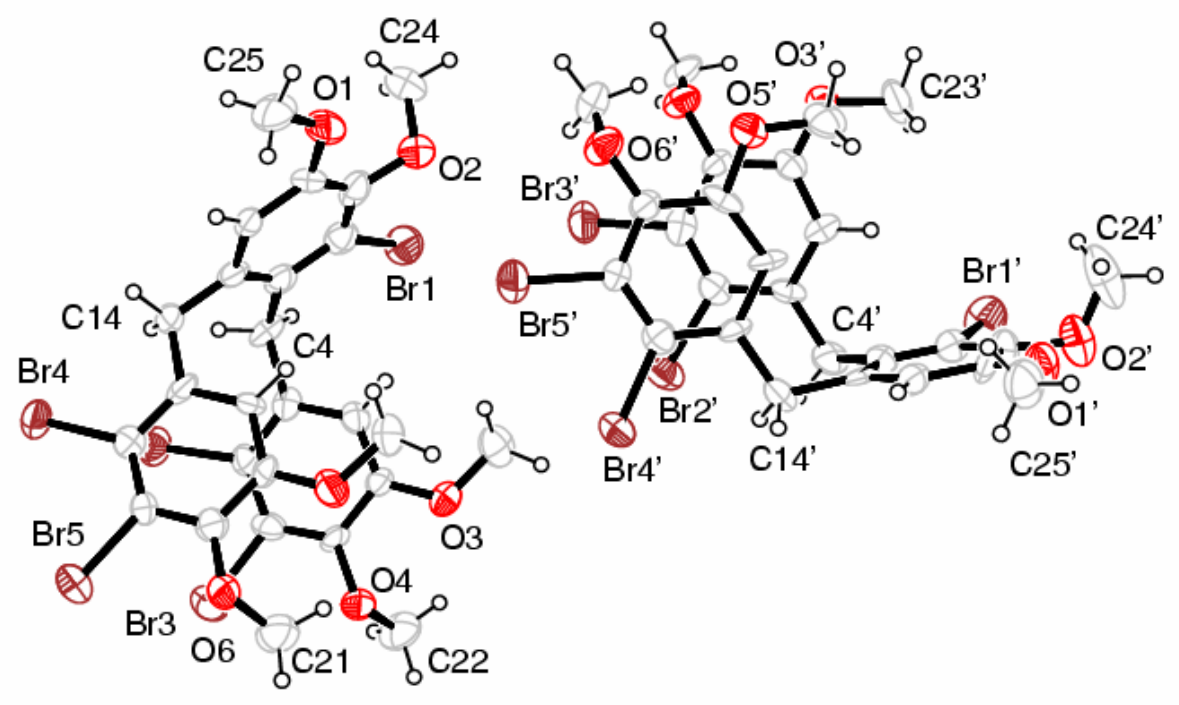

Figure 2. The molecular structure of pentabromide 19. The asymmetric unit contains half of the molecule. Displacement ellipsoids are shown at the 50\% probability level.

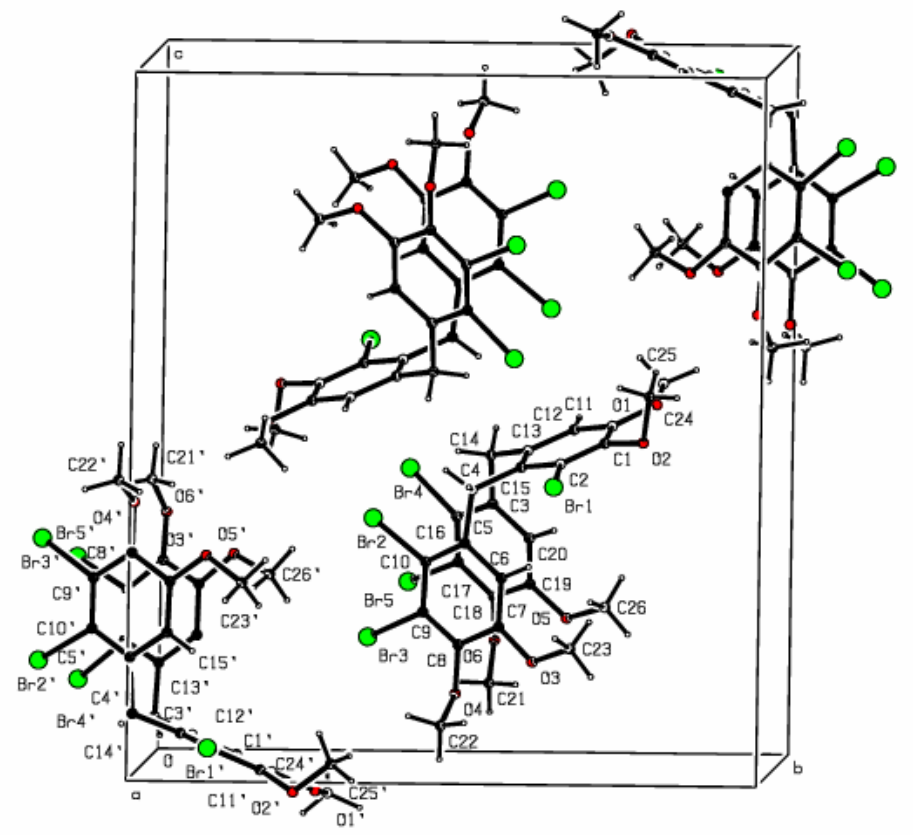

Figure 3. Packing diagram of pentabromide 19 along the $a$-axis. 


\section{Conclusions}

The first and short synthesis of brominated natural products $\mathbf{3}$ and $\mathbf{4}$ from the red alga Symphyocladia latiuscula as monobenzylphenol derivatives and $\mathbf{5}$ from the red alga Rhodomela confervoides as dibenzylphenol derivative were carried out.

\section{Experimental Section}

General. All chemicals and solvents are commercially available and were used after distillation or treatment with drying agents. Melting points were determined on a capillary melting apparatus (Buchi530) and are uncorrected. IR spectra were obtained from solutions in $0.1 \mathrm{~mm}$ cells with a Perkin-Elmer spectrophotometer. The ${ }^{1} \mathrm{H}$ - and ${ }^{13} \mathrm{C}$ - NMR spectra were recorded on a $200(50)$ and $400(100)-\mathrm{MHz}$ Varian spectrometer; $\delta$ in $\mathrm{ppm}, \mathrm{Me}_{4} \mathrm{Si}$ as the internal standard. Coupling constants are reported in Hz. Multiplicity is defined as s (singlet), d (doublet), t (triplet), br (broad), or m (multiplet). Elemental analyses were performed on a Leco CHNS-932 apparatus. All column chromatography was performed on silica gel (60-mesh, Merck). PLC is preparative thick-layer chromatography: $1 \mathrm{~mm}$ of silica gel $60 \mathrm{PF}$ (Merck) on glass plates.

Synthesis of 3,4-dimethoxybenzylacetate (7). 3,4-Dimethoxybenzyl alcohol (6) (10.0 g, 60 $\mathrm{mmol})$ was allowed to react at room temperature for 1 day with pyridine $(15 \mathrm{~mL})$ and $\mathrm{Ac}_{2} \mathrm{O}(10$ $\mathrm{mL}$ ) by applying a known method. ${ }^{5,6}$ The reaction mixture was poured into dilute aqueous $\mathrm{HCl}$ $(700 \mathrm{~mL})$ with ice and checked with $\mathrm{pH}$ paper. It was extracted with $\mathrm{CH}_{2} \mathrm{Cl}_{2}(2 \times 50 \mathrm{~mL})$, the extract was washed with cold $\mathrm{NaOH}(0.5 \%, 100 \mathrm{~mL})$ and water $(200 \mathrm{~mL})$, and dried over $\mathrm{CaCl}_{2}$. The solvent was evaporated and the 3,4-dimethoxybenzylacetate (7) $(11.97 \mathrm{~g}, 97 \%)$ was obtained as colourless liquid. ${ }^{1} \mathrm{H}-\mathrm{NMR}\left(400 \mathrm{MHz}, \mathrm{CDCl}_{3}\right) \delta 6.90(\mathrm{~d}, J=1.5 \mathrm{~Hz}, 1 \mathrm{H}), 6.87(\mathrm{dd}$, $J=8.4,1.5 \mathrm{~Hz}, 1 \mathrm{H}), 6.81(\mathrm{~d}, J=8.1 \mathrm{~Hz}, 1 \mathrm{H}), 5.00(\mathrm{~s}$, methylenic, $2 \mathrm{H}), 3.85(\mathrm{~s}, 3 \mathrm{H}), 3.83(\mathrm{~s}$, 3H), $2.04(\mathrm{~s}, 3 \mathrm{H}) ;{ }^{13} \mathrm{C}-\mathrm{NMR}\left(100 \mathrm{MHz}, \mathrm{CDCl}_{3}\right) \delta 171.10(\mathrm{CO}), 149.34(\mathrm{C}), 149.21(\mathrm{C}), 128.66$ (C), $121.52(\mathrm{CH}), 112.08(\mathrm{CH}), 111.26(\mathrm{CH}), 66.58\left(\mathrm{CH}_{2}\right), 56.09\left(\mathrm{OCH}_{3}\right), 56.06\left(\mathrm{OCH}_{3}\right), 21.23$ $\left(\mathrm{CH}_{3}\right)$.

Synthesis of 1,2,5-tribromo-3,4-dimethoxybenzene (13). ${ }^{7}$ To a solution of 1,2dihydroxybenzene $10(5.0 \mathrm{~g}, 45.4 \mathrm{mmol})$ in acetic acid (HOAc, $100 \mathrm{~mL})$ bromine $(58.0 \mathrm{~g}, 363.2$ mmol, 8 equivalent) was added at room temperature. After the reaction mixture was heated and refluxed for $18 \mathrm{~h}$, the solvent and excess bromine were removed. Tetrabromocatechol 11 was obtained in quantitative yield.

To a mixture of glacial HOAc $(15 \mathrm{ml})$, water $(5 \mathrm{ml})$ and tetrabromocatechol 11 (5.0 g, 11.74 mmol) zinc dust were added and the mixture was refluxed for 4 minutes. The filtered liquid was precipitated in water as solid and then tribromocatechol $\mathbf{1 2}$ was crystallized from boiling water as thin needles $(0.82 \mathrm{~g}, 20 \%)$. 
A solution of tribromocatechol $(0.9 \mathrm{~g}, 2.6 \mathrm{mmol})$ in tetrahydrofuran (THF, $10 \mathrm{~mL})$ was heated at $80^{\circ} \mathrm{C}$ and then tetramethyl ammonium bromide (catalytic amount), a solution of dimethyl sulfate (0.95 g, $7.53 \mathrm{mmol})$ in THF $(4.0 \mathrm{~mL})$ and a solution of $\mathrm{K}_{2} \mathrm{CO}_{3}(1.2 \mathrm{~g}, 12.1 \mathrm{mmol})$ in water (3.0 $\mathrm{mL})$ were added, respectively. After the reaction mixture was refluxed for 2 days, THF was removed and water was added to the reaction mixture $(30 \mathrm{~mL})$. The mixture was extracted with ethyl acetate $(3 \times 25 \mathrm{~mL})$. After the combined organic layer was dried over $\mathrm{Na}_{2} \mathrm{SO}_{4}$, it was filtered and the solvent was evaporated, 1,2,5-tribromo-3,4-dimethoxybenzene $(\mathbf{1 3})^{7}$ was obtained as $0.96 \mathrm{~g}(86 \%)$.

3,4,6-Tribromobenzene-1,2-diol (12). Mp 104-106 ${ }^{\circ} \mathrm{C}$ (Lit. ${ }^{7} 106^{\circ} \mathrm{C}$ ); ${ }^{1} \mathrm{H}-\mathrm{NMR}$ (400 MHz, $\left.\mathrm{CDCl}_{3}\right) 7.38(\mathrm{~s}, 1 \mathrm{H}), 5.86(\mathrm{~s}, 2 \mathrm{OH}) ;{ }^{13} \mathrm{C}-\mathrm{NMR}\left(100 \mathrm{MHz}, \mathrm{CDCl}_{3}\right) \delta 142.60$ (C), $140.84(\mathrm{C})$, $127.08(\mathrm{CH}), 115.21(\mathrm{C}), 112.09(\mathrm{C}), 108.84(\mathrm{C})$.

1,2,5-Tribromo-3,4-dimethoxybenzene (13). Mp 66-67 $\mathrm{C}$ (Lit. ${ }^{7} 69^{\circ} \mathrm{C}$ ); ${ }^{1} \mathrm{H}-\mathrm{NMR}(400 \mathrm{MHz}$, $\left.\mathrm{CDCl}_{3}\right) \delta 7.61(\mathrm{~s}, 1 \mathrm{H}), 3.89$ (s, methoxy, 3H), 3.88 (s, methoxy, 3H); ${ }^{13} \mathrm{C}-\mathrm{NMR}(100 \mathrm{MHz}$, $\left.\mathrm{CDCl}_{3}\right) \delta 152.89(\mathrm{C}), 150.91(\mathrm{C}), 131.66(\mathrm{CH}), 120.91(\mathrm{C}), 120.17(\mathrm{C}), 117.45$ (C), 61.17 (2 $\left.\mathrm{OCH}_{3}\right)$.

General procedure for coupling in PPA: synthesis of 1,2,4-tribromo-3-(2,3-dibromo-4,5dimethoxybenzyl)-5,6-dimethoxybenzene (15)

Polyphosphoric acid (PPA), prepared from conc. $\mathrm{H}_{3} \mathrm{PO}_{4}(85 \%, 0.83 \mathrm{~g})$ and $\mathrm{P}_{2} \mathrm{O}_{5}(1.49 \mathrm{~g}, 10.5$ $\mathrm{mmol})$, was heated to $80^{\circ} \mathrm{C}$ in a beaker $(100 \mathrm{~mL})$. To this mixture were added synthesized $9^{6}$ $(0.59 \mathrm{~g}, 1.45 \mathrm{mmol})$ and $14^{8}(0.43 \mathrm{~g}, 1.45 \mathrm{mmol})$ quickly. The mixture was stirred with a glass stick at $80^{\circ} \mathrm{C}$ for 45 minutes and was then carefully poured onto $10 \mathrm{~mL}$ of ice/water. The organic phase was extracted with EtOAc $(2 \times 40 \mathrm{~mL})$. The combined organic layers were dried over $\mathrm{Na}_{2} \mathrm{SO}_{4}$ and the solvent was evaporated. Pentabromide $15(0.92 \mathrm{~g}, 92 \%)$ was the sole product and was crystallized from ethyl acetate/hexane as white crystals. mp $159-162{ }^{\circ} \mathrm{C}$; ${ }^{1} \mathrm{H}-\mathrm{NMR}$ $\left(\mathrm{CDCL}_{3}, 400 \mathrm{MHz}\right) \delta 6.48(\mathrm{~s}, 1 \mathrm{H}), 4.49\left(\mathrm{~s}, \mathrm{CH}_{2}, 2 \mathrm{H}\right), 3.96$ (s, methoxy, 3H), 3.93 (s, methoxy, 6H), 3.89 (s, methoxy, 3H); ${ }^{13} \mathrm{C}-\mathrm{NMR}\left(100 \mathrm{MHz}^{\mathrm{CDCL}} 3\right) \delta 151.80$ (C), 151.46 (C), 151.12 (C), $149.91(\mathrm{C}), 135.86(\mathrm{C}), 134.52$ (C), $126.42(\mathrm{CH}), 123.73$ (C), $122.16(\mathrm{C}), 121.66$ (C), 119.70 (C), $116.92(\mathrm{C}), 61.16\left(\mathrm{OCH}_{3}\right), 61.12\left(\mathrm{OCH}_{3}\right), 61.08\left(\mathrm{OCH}_{3}\right), 61.06\left(\mathrm{OCH}_{3}\right), 44.94\left(\mathrm{CH}_{2}\right)$; IR $\left(\mathrm{CH}_{2} \mathrm{Cl}_{2}, \mathrm{~cm}^{-1}\right): 3855,3445,2939,2857,1639,1453,1419,1386,1370,1311,1282,1155,1134$, 1062, 1034, 1001, 961, 926, 852, 796, 769, 738, 702, 642, 524; Anal. Calcd for $\mathrm{C}_{17} \mathrm{H}_{15} \mathrm{Br}_{5} \mathrm{O}_{4}: \mathrm{C}$, 29.90; H, 2.21. Found: C, 29.89; H, 2.21.

Synthesis of 1,2,4-tribromo-5,6-dimethoxy-3-(2,3,6-tribromo-4,5-dimethoxybenzyl)benzene (16). The reaction was performed by following the standard procedure described above for the synthesis of 15 . Bromoalcohol $9^{6}(0.5 \mathrm{~g}, 1.25 \mathrm{mmol})$, tribromoveratrole $13^{7}(0.46 \mathrm{~g}, 1.25 \mathrm{mmol})$, $\mathrm{H}_{3} \mathrm{PO}_{4}(85 \%, 0.70 \mathrm{~g})$ and $\mathrm{P}_{2} \mathrm{O}_{5}(1.26 \mathrm{~g})$ were used in the reaction. The reaction lasted for 1 hour. Hexabromide $16(0.91 \mathrm{~g}, 97 \%)$ was the sole product and was crystallized from ethyl acetate as white crystals. mp 124-126 ${ }^{\circ} \mathrm{C} ;{ }^{1} \mathrm{H}-\mathrm{NMR}\left(\mathrm{CDCL}_{3}, 400 \mathrm{MHz}\right) \delta 4.91\left(\mathrm{~s}, \mathrm{CH}_{2}, 2 \mathrm{H}\right), 3.90$ (s, methoxy, 6H), 3.87 (s, methoxy, 6H); ${ }^{13} \mathrm{C}-\mathrm{NMR}$ (100 MHz, $\mathrm{CDCl}_{3}$ ), $\delta 150.82(\mathrm{C}), 150.80(\mathrm{C})$, $136.27(\mathrm{C}), 123.50(\mathrm{C}), 122.22(\mathrm{C}), 122.00(\mathrm{C}), 61.19\left(\mathrm{OCH}_{3}\right), 61.02\left(\mathrm{OCH}_{3}\right), 47.86\left(\mathrm{CH}_{2}\right)$; IR 
$\left(\mathrm{CH}_{2} \mathrm{Cl}_{2}, \mathrm{~cm}^{-1}\right)$ 2934, 2854, 1741, 1519, 1452, 1393, 1369, 1311, 1281, 1213, 1156, 1058, 1039, 1011, 963, 943, 910, 878, 824, 766, 699, 527; Anal. Calcd for $\mathrm{C}_{17} \mathrm{H}_{14} \mathrm{Br}_{6} \mathrm{O}_{4}: \mathrm{C}, 26.81$; H, 1.85 . Found: C, 26.73; H, 1.86 .

Reaction of (2,3-dibromo-4,5-dimethoxyphenyl)methanol (17) and 1-bromo-2,3dimethoxybenzene (18). The reaction was carried out by following the standard procedure described above for the synthesis of $\mathbf{1 5}$. Bromoalcohol $17^{11}$ (2.0 g, $6.13 \mathrm{mmol}, 2.0$ equivalent), 1 bromo-2,3-dimethoxybenzene $\mathbf{1 8}^{12}$ (0.67 g, $3.1 \mathrm{mmol}, 1.0$ equivalent), $\mathrm{H}_{3} \mathrm{PO}_{4}(85 \%, 3.50 \mathrm{~g})$ and $\mathrm{P}_{2} \mathrm{O}_{5}(6.29 \mathrm{~g})$ were used in the reaction. The reaction lasted for $1.0 \mathrm{~h}$. The residue $(2.71 \mathrm{~g})$ was subjected to column chromatography on silica gel (150 g) using ethyl acetate/hexane (5:95) to give 19 (1.20 g, $1.44 \mathrm{mmol}, 47 \%)$ and 20 (1.13 g, $1.35 \mathrm{mmol}, 44 \%)$, respectively.

\section{2,3-Dibromo-1-[3-bromo-2-(2,3-dibromo-4,5-dimethoxybenzyl)-4,5-dimethoxybenzyl]-4,5-}

dimethoxybenzene (19). It was crystallized from ethyl acetate/hexane; mp $132-135^{\circ} \mathrm{C} ;{ }^{1} \mathrm{H}-\mathrm{NMR}$ $\left(400 \mathrm{MHz}, \mathrm{CDCl}_{3}\right) \delta 6.60$ (s, aromatic, $\left.1 \mathrm{H}\right), 6.45$ (s, aromatic, $\left.1 \mathrm{H}\right), 6.14(\mathrm{~s}$, aromatic, $1 \mathrm{H}), 4.20$ (s, methylenic, 2H), 3.96 (s, methylenic, 2H), 3.88 (s, methoxy, 3H), 3.80 (s, methoxy, $3 \mathrm{H}), 3.79$ (s, methoxy, 3H), $3.78\left(\mathrm{~s}\right.$, methoxy, 3H), $3.70(\mathrm{~s}$, methoxy, $3 \mathrm{H}), 3.58(\mathrm{~s}$, methoxy, $3 \mathrm{H}) ;{ }^{13} \mathrm{C}-$ NMR (100 MHz, APT, $\left.\mathrm{CDCl}_{3}\right) \delta 152.57$ (C), 152.48 (C), 152.45 (C), 146.68 (C), 146.23 (C), 145.80 (C), 136.24 (C), 135.62 (C), 135.44 (C), 130.13 (C), 123.06 (CH), 122.33 (C), 121.88 (C), $118.23(\mathrm{C}), 117.70(\mathrm{C}), 114.16(\mathrm{CH}), 114.04(\mathrm{CH}), 112.13(\mathrm{CH}), 60.76\left(2 \mathrm{OCH}_{3}\right), 60.71$ $\left(\mathrm{OCH}_{3}\right), 56.37\left(2 \mathrm{OCH}_{3}\right), 56.29\left(\mathrm{OCH}_{3}\right), 42.35\left(\mathrm{CH}_{2}\right), 40.71\left(\mathrm{CH}_{2}\right) ; \mathrm{IR}\left(\mathrm{CH}_{2} \mathrm{Cl}_{2}, \mathrm{~cm}^{-1}\right): 2995$, 2962, 2936, 2842, 2824, 1583, 1549, 1468, 1422, 1397, 1375, 1309, 1262, 1200, 1057, 1008, 853, 822, 736, 616; Anal. Calcd for $\mathrm{C}_{26} \mathrm{H}_{25} \mathrm{Br}_{5} \mathrm{O}_{6}$ : C, 37.49; H, 3.03. Found: C, 37.44; H, 2.99.

\section{2,3-Dibromo-1-[4-bromo-5-(2,3-dibromo-4,5-dimethoxybenzyl)-2,3-dimethoxybenzyl]-4,5-}

dimethoxybenzene (20): It was crystallized from ethyl acetate/hexane; mp $164-166^{\circ} \mathrm{C} ;{ }^{1} \mathrm{H}-\mathrm{NMR}$ $\left(400 \mathrm{MHz}, \mathrm{CDCl}_{3}\right) \delta 6.61$ (s, aromatic, $\left.1 \mathrm{H}\right), 6.58$ (s, aromatic, $\left.1 \mathrm{H}\right), 6.36$ (s aromatic, $\left.1 \mathrm{H}\right), 4.12$ (s, methylenic, 2H), 4.01 (s, methylenic, 2H), 3.90 (s, methoxy, 3H), 3.85 (s, methoxy, 3H), 3.84 (s, methoxy, 3H), 3.82 (s, methoxy, 3H), 3.73 (s, methoxy, 3H), $3.72(\mathrm{~s}$, methoxy, $3 \mathrm{H}) ;{ }^{13} \mathrm{C}-$ NMR (100 MHz, APT, $\left.\mathrm{CDCl}_{3}\right) \delta 152.74$ (C), 152.63 (C), 150.76 (C), 150.68 (C), 146.67 (C), 146.56 (C), 136.90 (C), 136.41 (C), 134.87 (C), 132.72 (C), 126.23 (CH), 122.19 (C), 122.14 (C), 118.79 (C), 118.22 (C), $117.94(\mathrm{C}), 114.02(2 \mathrm{CH}), 60.81\left(2 \mathrm{OCH}_{3}\right), 60.79\left(\mathrm{OCH}_{3}\right), 60.65$ $\left(\mathrm{OCH}_{3}\right), 56.46\left(\mathrm{OCH}_{3}\right), 56.44\left(\mathrm{OCH}_{3}\right), 43.74\left(\mathrm{CH}_{2}\right), 37.77\left(\mathrm{CH}_{2}\right) ; \mathrm{IR}\left(\mathrm{CH}_{2} \mathrm{Cl}_{2}, \mathrm{~cm}^{-1}\right): 3000$, 2962, 293, 2841, 1593, 1549, 1469, 1373, 1310, 1283, 1193, 1162, 1101, 1057, 1039, 1006, 813, 736; Anal. Calcd for $\mathrm{C}_{26} \mathrm{H}_{25} \mathrm{Br}_{5} \mathrm{O}_{6}$ : C, 37.49; H, 3.03. Found: C, 37.48; H, 3.02.

Synthesis of 2,3-dibromo-1-(2-bromo-3,4-dimethoxybenzyl)-4,5-dimethoxybenzene (21). The reaction was carried out by following the standard procedure described above for the synthesis of 8. Bromoalcohol $17^{11}(0.50 \mathrm{~g}, 1.53 \mathrm{mmol}, 1.0$ equivalent), 1-bromo-2,3dimethoxybenzene $(\mathbf{1 8})^{12}\left(0.33 \mathrm{~g}, 1.53 \mathrm{mmol}, 1.0\right.$ equivalent), $\mathrm{H}_{3} \mathrm{PO}_{4}(85 \%, 0.87 \mathrm{~g})$ and $\mathrm{P}_{2} \mathrm{O}_{5}$ $(1.57 \mathrm{~g})$ were used in the reaction. The reaction lasted for $1 \mathrm{~h}$. Monosubstituted product 21 (0.91 $\mathrm{g}, 96 \%$ ) was the sole product and was crystallized from ethyl acetate/hexane as white crystals. mp 97-99 ${ }^{\circ} \mathrm{C} ;{ }^{1} \mathrm{H}-\mathrm{NMR}\left(400 \mathrm{MHz}, \mathrm{CDCl}_{3}\right) \delta 6.80(\mathrm{~d}, J=8.4 \mathrm{~Hz}$, A part of AB system, aromatic, $1 \mathrm{H}), 6.67(\mathrm{~d}, J=8.43 \mathrm{~Hz}, \mathrm{~B}$ part of AB system, aromatic, $1 \mathrm{H}), 6.57$ (s, aromatic, 1H), 4.16 (s, 
$\mathrm{CH}_{2}, 2 \mathrm{H}$ ), 3.87 (s, methoxy, 3H), 3.86 (s, methoxy, 3H), 3.84 (s, methoxy, 3H), 3.73 (s, methoxy, 3H); ${ }^{13} \mathrm{C}-\mathrm{NMR}\left(100 \mathrm{MHz}, \mathrm{CDCl}_{3}\right), \delta 152.74(\mathrm{C}), 152.47$ (C), 147.00 (C), 146.52 (C), $136.88(\mathrm{C}), 131.72(\mathrm{C}), 125.37(\mathrm{CH}), 122.18(\mathrm{C}), 120.81(\mathrm{C}), 118.18(\mathrm{C}), 113.78(\mathrm{CH}), 111.54$ $(\mathrm{CH}), 60.74\left(\mathrm{OCH}_{3}\right), 60.68\left(\mathrm{OCH}_{3}\right), 56.35\left(\mathrm{OCH}_{3}\right), 56.30\left(\mathrm{OCH}_{3}\right), 43.61\left(\mathrm{CH}_{2}\right) ; \mathrm{IR}\left(\mathrm{CH}_{2} \mathrm{Cl}_{2}\right.$, $\left.\mathrm{cm}^{-1}\right)$ : 3686, 2992, 2937, 2835, 1592, 1549, 1485, 1469, 1422, 1375, 1284, 1202, 1161, 1059, 1033, 1007, 814; Anal. Calcd for $\mathrm{C}_{17} \mathrm{H}_{17} \mathrm{Br}_{3} \mathrm{O}_{4}$ : C, 38.89; H, 3.26. Found: C, 38.79; H, 3.28.

Synthesis of 1,2-dibromo-3,4-dimethoxybenzene (22). To a stirring solution of 1-bromo-2,3dimethoxybenzene (18) $(0.217 \mathrm{~g}, 1.0 \mathrm{mmol})$ in $\mathrm{CHCl}_{3}(20 \mathrm{~mL})$ was added dropwise a solution of bromine $(0.17 \mathrm{~g}, 1.1 \mathrm{mmol})$ in $\mathrm{CHCl}_{3}(10 \mathrm{~mL})$ at room temperature (RT) in 1 minute. After the reaction mixture was stirred at RT for 1 day, the solvent was evaporated. The residue was subjected to column chromatography on silica gel $\left(\mathrm{SiO}_{2}, 60 \mathrm{~g}\right)$ and eluted with EtOAc/hexane (1:40). 1,2,3-Tribromo-4,5-dimethoxybenzene $(\mathbf{1 3})^{7}$ (147 $\left.\mathrm{mg}, \% 4\right)$ and 1,2-dibromo-3,4dimethoxybenzene (22) (0.27 g, \%94) were isolated, consecutively. Liquid; ${ }^{1} \mathrm{H}-\mathrm{NMR}$ (400 MHz, $\left.\mathrm{CDCl}_{3}\right): \delta 7.33(\mathrm{~d}, J=9.0 \mathrm{~Hz}, \mathrm{~A}$ part of AB system, aromatic, $1 \mathrm{H}), 6.77(\mathrm{~d}, J=9.0 \mathrm{~Hz}$, B part of $\mathrm{AB}$ system, aromatic, $1 \mathrm{H}), 3.86(\mathrm{~s}$, methoxy, $3 \mathrm{H}), 3.84$ (s, methoxy, $3 \mathrm{H})$ ) ${ }^{13} \mathrm{C}-\mathrm{NMR}(100 \mathrm{MHz}$, $\left.\mathrm{CDCl}_{3}\right) \delta 153.01(\mathrm{C}), 128.38(\mathrm{CH}$ and $\mathrm{C}), 121.37(\mathrm{C}), 115.99(\mathrm{C}), 112.78(\mathrm{CH}), 60.74\left(\mathrm{OCH}_{3}\right)$, $56.48\left(\mathrm{OCH}_{3}\right)$; IR $\left(\mathrm{CH}_{2} \mathrm{Cl}_{2}, \mathrm{~cm}^{-1}\right): 3441,3003,2937,2838,2549,2069,1575,1468,1427,1388$, 1290, 1258, 1224, 1158, 1134, 1036, 1005, 861, 797, 748, 653, 620, 589, 507; Anal. Calcd $\left(\mathrm{C}_{8} \mathrm{H}_{8} \mathrm{Br}_{2} \mathrm{O}_{2}\right)$ : C 32.47, H 2.72; Found: C 32.49, H 2.69.

Standard procedure for demethylation of compounds with OMe by ether cleavage. Synthesis of 3,4,6-tribromo-5-(2,3-dibromo-4,5-dihydroxybenzyl)benzene-1,2-diol (3). A solution of pentabromide $15(0.52 \mathrm{~g}, 0.76 \mathrm{mmol})$ in $\mathrm{CH}_{2} \mathrm{Cl}_{2}(12 \mathrm{~mL})$ was cooled to $0^{\circ} \mathrm{C}$ and then a solution of $\mathrm{BBr}_{3}(0.5 \mathrm{~mL})$ in $\mathrm{CH}_{2} \mathrm{Cl}_{2}(5.2 \mathrm{~mL})$ was added dropwise under $\mathrm{N}_{2}(\mathrm{~g})$ over 5 minutes. After the cold bath was removed, the mixture was stirred at RT and under $\mathrm{N}_{2}$ for 1 day. Methanol $(30 \mathrm{~mL})$ was slowly added over 15 minutes and then the solvent was evaporated. After water (40 $\mathrm{mL})$ and EtOAc $(50 \mathrm{~mL})$ were added, the mixture was shaken. The organic phase was separated and the water phase was extracted with EtOAc $(2 \times 30 \mathrm{~mL})$. The combined organic phases were dried over $\mathrm{Na}_{2} \mathrm{SO}_{4}$ and the solvent was evaporated. The natural product bromophenol $3(0.5 \mathrm{~g}$, $96 \%)$ was obtained and crystallized from ethyl acetate/hexane as amorphous; $\mathrm{mp} 165-167^{\circ} \mathrm{C}$ (lit. $\left.{ }^{3 \mathrm{a}} 168-172^{\circ} \mathrm{C}\right) ;{ }^{1} \mathrm{H}-\mathrm{NMR}\left(400 \mathrm{MHz}, \mathrm{CD}_{3} \mathrm{COCD}_{3}\right) \delta 8.65$ (s, $\left.4 \mathrm{OH}\right), 6.25$ (s, 1H), 4.42 (s, methylenic, $2 \mathrm{H}) ;{ }^{13} \mathrm{C}-\mathrm{NMR}\left(100 \mathrm{MHz}, \mathrm{CD}_{3} \mathrm{COCD}_{3}\right) \delta 144.33$ (C), 143.04 (C), 143.71 (C), 142.10 (C), 130.68 (C), 130.17 (C), 121.56 (CH), 117.75 (C), 113.40 (2C), $111.61(\mathrm{C}), 108.97$ (C), $44.04\left(\mathrm{CH}_{2}\right)$.

Synthesis of bromophenols 4, 5 and 23 from the corresponding compounds 16, 19 and 20, respectively. The standard procedure described above for the synthesis of $\mathbf{3}$ with $\mathrm{BBr}_{3}$ was applied. From these reactions, bromophenols 4, 5 and 23 were obtained.

3,4,6-Tribromo-5-(2,3,6-tribromo-4,5-dihydroxybenzyl)benzene-1,2-diol (4). Amorphous; (0.564 g, 94\%); mp 164-168 ${ }^{\circ} \mathrm{C}$ (lit. $\left.{ }^{3 \mathrm{a}} 168-172^{\circ} \mathrm{C}\right) ;{ }^{1} \mathrm{H}-\mathrm{NMR}\left(400 \mathrm{MHz}, \mathrm{CD}_{3} \mathrm{COCD}_{3}\right) \delta 8.65(\mathrm{~s}, 4$ $\mathrm{OH}), 4.84\left(\mathrm{~s}, \mathrm{CH}_{2}, 2 \mathrm{H}\right) ;{ }^{13} \mathrm{C}-\mathrm{NMR}\left(100 \mathrm{MHz}, \mathrm{CD}_{3} \mathrm{COCD}_{3}\right) \delta 143.30(2 \mathrm{C}), 131.15(\mathrm{C}), 117.82$ (C), $113.78(\mathrm{C}), 113.63(\mathrm{C}), 46.94\left(\mathrm{CH}_{2}\right)$. 


\section{3,4-Dibromo-5-[3-bromo-2-(2,3-dibromo-4,5-dihydroxybenzyl)-4,5-dihydroxybenzyl]}

benzene-1,2-diol (5). Pale brown amorphous solid; (0.40 g, 95\%); mp 234-236 ${ }^{\circ} \mathrm{C}$ (lit. ${ }^{4} 237$ $\left.238^{\circ} \mathrm{C}\right){ }^{1} \mathrm{H}-\mathrm{NMR}\left(400 \mathrm{MHz}, \mathrm{CD}_{3} \mathrm{COCD}_{3}\right) \delta 8.82(\mathrm{~s}, \mathrm{OH}, 1 \mathrm{H}), 8.71(\mathrm{~s}, \mathrm{OH}, 1 \mathrm{H}), 8.69(\mathrm{~s}, \mathrm{OH}$, $1 \mathrm{H}), 8.27(\mathrm{~s}, \mathrm{OH}, 1 \mathrm{H}), 8.15(\mathrm{~s}, \mathrm{OH}, 1 \mathrm{H}), 8.00(\mathrm{~s}, \mathrm{OH}, 1 \mathrm{H}), 6.56(\mathrm{~s}$, aromatic, $1 \mathrm{H}), 6.50(\mathrm{~s}$, aromatic, $1 \mathrm{H}), 6.21(\mathrm{~s}$, aromatic, $1 \mathrm{H}), 4.05(\mathrm{~s}$, methylenic, $2 \mathrm{H}), 3.78(\mathrm{~s}$, methylenic, $2 \mathrm{H})$; ${ }^{13} \mathrm{C}$ NMR (100 MHz, $\left.\mathrm{CD}_{3} \mathrm{COCD}_{3}\right) \delta 144.97$ (C), 144.87 (C), 144.51 (2C), 143.26 (C), 142.95 (C), $141.96(\mathrm{C}), 132.25(\mathrm{C}), 131.19(2 \mathrm{C}), 128.65(\mathrm{C}), 116.30(\mathrm{C}), 116.25(\mathrm{CH}), 115.83(\mathrm{CH}), 114.41$ (C), $114.27(\mathrm{CH}), 113.34(\mathrm{C}), 113.15(\mathrm{C}), 40.34\left(\mathrm{CH}_{2}\right), 39.48\left(\mathrm{CH}_{2}\right)$; IR $\left(\mathrm{CH}_{3} \mathrm{OH}, \mathrm{cm}^{-1}\right)$ : 3571, 3325, 2967, 2918, 2863, 1594, 1480, 1403, 1276, 1206, 1033; Anal. Calcd for $\mathrm{C}_{20} \mathrm{H}_{13} \mathrm{Br}_{5} \mathrm{O}_{6}$ : C, 32.08; H, 1.75. Found: C, 32.08; H, 1.77.

\section{3,4-Dibromo-5-[4-bromo-5-(2,3-dibromo-4,5-dihydroxybenzyl)-2,3-dihydroxybenzyl]}

benzene-1,2-diol (23). Pale brown amorphous solid; (0.43 g, 95\%); mp 99-103 ${ }^{\circ} \mathrm{C} ;{ }^{1} \mathrm{H}-\mathrm{NMR}(400$ $\left.\mathrm{MHz} \mathrm{CDCl}_{3}\right) \delta 8.70(\mathrm{~s}, \mathrm{OH}, 1 \mathrm{H}), 8.69(\mathrm{~s}, \mathrm{OH}, 1 \mathrm{H}), 8.16(\mathrm{~s}, \mathrm{OH}, 1 \mathrm{H}), 8.14(\mathrm{~s}, \mathrm{OH}, 1 \mathrm{H}), 8.05(\mathrm{~s}$, $\mathrm{OH}, 1 \mathrm{H}), 7.93(\mathrm{~s}, \mathrm{OH}, 1 \mathrm{H}), 6.60(\mathrm{~s}$, aromatic, $1 \mathrm{H}), 6.51$ (s, aromatic, $1 \mathrm{H}), 6.43$ (s, aromatic, $1 \mathrm{H})$, 3.99 (s, methylenic, 2H), 3.97 (s, methylenic, $2 \mathrm{H}) ;{ }^{13} \mathrm{C}-\mathrm{NMR}\left(100 \mathrm{MHz}, \mathrm{CDCl}_{3}\right) \delta 144.87(2 \mathrm{C})$, 144.84 (2C), 143.14 (C), 143.04 (C), 142.98 (C), 142.91 (C), 132.22 (C), 130.05 (C), 125.83 (C), $123.83(\mathrm{C}$ and $\mathrm{CH}), 115.98(\mathrm{CH}), 115.75(\mathrm{CH}), 114.00(\mathrm{C}), 113.15(\mathrm{C}), 111.18(\mathrm{C}), 42.84\left(\mathrm{CH}_{2}\right)$, $36.95\left(\mathrm{CH}_{2}\right)$; IR $\left(\mathrm{CH}_{3} \mathrm{OH}, \mathrm{cm}^{-1}\right): 3571,3467,3391,2973,2918,2863,2835,2313,1594,1472$, 1405, 1273, 1183, 1055, 1033, 857; Anal. Calcd for $\mathrm{C}_{20} \mathrm{H}_{13} \mathrm{Br}_{5} \mathrm{O}_{6}$ : C, 32.08; H, 1.75. Found: C, $32.03 ; \mathrm{H}, 1.79$.

NMR spectra of natural products $\mathbf{3 , 4}$ and $\mathbf{5}$ are consistent with data given in the literature. . $^{3 a}$

\section{X-Ray structure determination}

For the crystal structure determination, the single crystal of the compound pentabromide 19 was used for data collection on a four-circle Rigaku R-AXIS RAPID-S diffractometer (equipped with a two-dimensional area IP detector). The graphite-monochromatized Mo $\mathrm{K}_{\alpha}$ radiation $(\lambda=0.71073 \AA)$ and oscillation scans technique with $\Delta \omega=5^{\circ}$ or one image were used for data collection. The lattice parameters were determined by the least-squares methods on the basis of all reflections with $F^{2}>2 \sigma\left(F^{2}\right)$. Integration of the intensities, correction for Lorentz and polarization effects and cell refinement were performed using CrystalClear (Rigaku/MSC Inc., 2005) software. ${ }^{13}$ The structures were solved by direct methods using SHELXS-97 ${ }^{14}$ and refined by a full-matrix least-squares procedure using the program SHELXL-97. ${ }^{14} \mathrm{H}$ atoms were positioned geometrically and refined using a riding model by fixing the aromatic $\mathrm{C}-\mathrm{H}$ distances at $0.93 \AA$ and methyl $\mathrm{C}-\mathrm{H}$ distances at $0.96 \AA\left[\mathrm{U}_{\mathrm{iso}}(\mathrm{H})=1.2 \mathrm{U}_{\mathrm{eq}}(\mathrm{C})\right.$ and $\mathrm{U}_{\text {iso }}(\mathrm{H})=1.5 \mathrm{U}_{\text {eq }}($ methyl C)]. The final difference Fourier maps showed no peaks of chemical significance. Crystal data for pentabromide 19: $\mathrm{C}_{26} \mathrm{H}_{25} \mathrm{Br}_{5} \mathrm{O}_{6}$, crystal system, space group: triclinic, $\mathrm{P}-1$; (no:2); unit cell dimensions: $a=8.4083(2), \quad b=17.3134(4), \quad c=19.3196(5) \AA, \quad \alpha=88.63(3) \quad \beta=89.37(4)$, $\gamma=86.51(3)^{\circ}$; volume: $2806.3(2) \AA^{3} ; Z^{\prime}=4$; calculated density: $1.97 \mathrm{mg} / \mathrm{m}^{3}$; absorption coefficient:

$7.200 \mathrm{~mm}^{-1} ; F(000)$ : $1616 ; \theta$ range for data collection $2.4-26.4^{\circ}$; refinement method: full-matrix least-square on $F^{2}$; data/parameters: 11455/668; goodness-of-fit on $F^{2}: 1.278$; final $R$ indices 
$[I>2 \sigma(I)]: R_{1}=0.098, w R_{2}=0.157 ; R$ indices (all data): $R_{1}=0.227, w R_{2}=0.178$; largest diff. peak and hole: 0.609 and -0.582 e $\AA^{-3}$; CCDC- 743502 .

\section{Acknowledgements}

The authors are indebted to the Department of Chemistry (Atatürk University) and TÜBİTAK (Project No: 107T348) for financial support and to Dr. Ebru Mete and Barış Anıl for their technical assistance.

\section{References}

1. (a) Gribble, G. W. J. Nat. Prod. 1992, 55, 1353. (b) Gribble, G. W. Chem. Soc. Rev. 1999, 28,335 .

2. (a) Lee, H. S.; Lee, T. H.; Lee, J. H.; Chae, C. S.; Chung, S. C.; Shin, D. S.; Shin, J.; Oh, K. B. J. Agric. Food Chem. 2007, 55, 6923. (b) Xu, X.; Song, F.; Wang, S.; Li, S.; Xiao, F.; Zhao, J.; Yang, Y.; Shang, S.; Yang, L.; Shi, J. J. Nat. Prod. 2004, 67, 1661. (c) Kurata, K.; Taniguchii, K.; Takashima, K.; Hayashi, I.; Suzuki, M. Phytochemistry 1997, 45, 485. (d) Oh, K. B.; Lee, J. H.; Chung, S. C.; Shin, J.; Shin, H. J.; Kim, H. K.; Lee, H. S. Bioorg. Med. Chem. Lett. 2008, 18, 104. (e) Xu, N.; Fan, X.; Yan, X.; Li, X.; Niu, R.; Tseng, C. K. Phytochemistry 2003, 62, 1221. (f) Fan, X.; Ma, C.; Han, L.; Shi, D.; Liu, Q. CN Patent 1,853,618, 2006; Chem. Abstr. 2007, 146, 13018v. (g) Shi, D. Y; Xu, F.; He, J.; Jing, L.; Li, J.; Fan, X; Han, L. J. Chin. Sci. Bull. 2008, 53, 2476.

3. (a) Wang, W.; Okada, Y.; Shi, H.; Wang, Y.; Okuyama, T. J. Nat. Prod. 2005, 68, 620. (b) Duan, X. J.; Li, X. M.; Wang, B. G. J. Nat. Prod. 2007, 70, 1210.

4. (a) Fan, X.; Xu, N. J.; Shi, J. G. J. Nat. Prod. 2003, 66, 455. (b) Xu, N. J.; Fan, X.; Yang, Y. C.; Shi, J. G. Chin. Chem. Lett. 2003, 14, 807.

5. (a) Şengül, M. E.; Menzek, A.; Şahin, E.; Arık, M.; Saraçoğlu, N. Tetrahedron 2008, 64, 7289. (b) Menzek, A.; Kazaz, C.; Eryiğit F.; Cengiz, M. J. Chem. Res. Synop. 2004, 210.

6. Mori, T.; Bando, H.; Kanaiwa, Y.; Amiya, T.; Kurata, K. Chem. Pharm. Bull. 1983, 31, 1754.

7. Kohn, M.; Steiner, L. J. Org. Chem. 1947, 12, 30.

8. Albrecht, M. Synthesis 1996, 230.

9. (a) Burwell, R. L.; Archer, S. J. Am. Chem. Soc. 1942, 64, 1032. (b) Harig, M.; Neumann, B.;Stammler, H. G.; Kuck, D. Eur. J. Org. Chem. 2004, 2381. (c) Akbaba, Y.; Balaydın, H. T.; Göksu, S.; Şahin, E.; Menzek, A. Helv Chim Acta 2010; DOI: 10.1002/hlca.200900300 (In press). "

10. (a) Talaz, O.; Gülçin, İ.; Göksu, S.; Saraçoğlu, N. Bioorg Med Chem. 2009, 17, 6583. (b) Vickery, E. H.; Pahler, L. F.; Eisenbraun, E. J. J. Org. Chem. 1979, 44, 4444. 
11. (a) Ford, P. W.; Davidson, B. S. J. Org. Chem. 1993, 58, 4522. (b) Hodgkin, J. H.; Craigie, J. S.; McInnes, A. G. Can. J. Chem. 1966, 44, 74. (c) Glombitza, K. W.; Sukopp, I.; Wiedenfeld, H. Planta Medica 1985, 437.

12. Stevens, R. V.; Bisacchi, G. S. J. Org. Chem. 1982, 47, 2393.

13. Rigaku/MSC, Inc., 9009 New Trails Drive, The Woodlands, TX 77381.

14. Sheldrick, G. M., SHELXS97 and SHELXL97, University of Göttingen, Germany, 1997 